\title{
Judicial and Extra-Judicial Challenges in the EU Multi- and Cross-Level Administrative Framework ${ }^{\dagger}$
}

\author{
Mariolina Eliantonio ${ }^{1, *}$ (iD) and Nikos Vogiatzis ${ }^{2, * *}$ \\ ${ }^{1}$ Department of Public Law, Maastricht University, Maastricht, Netherlands and ${ }^{2}$ School of Law, University of Essex, \\ Colchester, United Kingdom \\ Corresponding author: Nikos Vogiatzis, Email: n.vogiatzis@essex.ac.uk
}

(Received 02 April 2021; accepted 11 April 2021)

\begin{abstract}
This Special Issue aims at interrogating the judicial and extra-judicial challenges that arise from the EU complex administrative framework, which can be characterized as both multi-level—arising from the vertical cooperation between EU and national authorities-and cross-level-arising from horizontal cooperation between national authorities themselves. It starts from the premise that there may be decisions affecting natural and legal persons which cannot be easily reviewed judicially, whereas in extra-judicial cooperation, the lack of common standards or practices across Member States may undermine the effectiveness of EU policies and objectives. This Special Issue focuses on various mechanisms of horizontal and vertical cooperation, such as regulatory patterns giving rise to transnational administrative acts and mutual recognition systems, case studies of composite procedures in the field of the genetically modified organisms regime and information sharing in asylum policy, as well as multi-level inspection activities for the enforcement of EU law. It further complements the analysis on the judicial challenges arising from those cooperative structures with an examination of extra-judicial avenues of control in the EU administrative framework, namely the "EU queries" process and the cooperation of ombud offices, as well as the audit of the EU budget. This Special Issue reflects on ways to overcome the current challenges of, and seeks to prompt further research on, the multi-layered EU system of administrative cooperation.
\end{abstract}

Keywords: Multi-level administration; administrative cooperation; effective judicial protection; extra-judicial accountability; implementation of EU law

*Professor of European and Comparative Administrative Law and Procedure, Department of Public Law, Faculty of Law, Maastricht University.

${ }^{* *}$ Senior Lecturer, School of Law, University of Essex.

${ }^{\dagger}$ The PDF version of this article has been updated since original publication. A notice detailing the change has also been published.

This project has its origins in panels that were convened by the editors for the UACES Annual Conference in Krakow (2017) and their participation in the "EU Multilevel Administration and Governance" working group of the EGPA Conference in Lausanne (2018). Yet, the key event that led to the realization of this Special Issue was a workshop, with the same title, that was organized in July 2019 in Brussels at Maastricht University's Brussels Campus. Financial support for this workshop was generously provided by the University of Maastricht and the University of Liverpool Research Development Fund. The editors would also like to express their gratitude to colleagues who acted as chairs and discussants on that day: Natassa Athanasiadou, Filipe Brito Bastos, Darryn Nyatanga, and Lilian Tsourdi. We would also like to thank the GLJ editorial team for assistance throughout the different stages of the process and, in particular, Matej Avbelj, who read all the Articles after the completion of our review.

(C) The Author(s) 2021. Published by Cambridge University Press on behalf of the German Law Journal. This is an Open Access article, distributed under the terms of the Creative Commons Attribution licence (http://creativecommons.org/licenses/by/4.0/), which permits unrestricted re-use, distribution, and reproduction in any medium, provided the original work is properly cited. 


\section{A. Introduction}

In the system of executive federalism ${ }^{1}$ set up by the treaties, it is the Member States that are primarily responsible for the implementation of EU law at the domestic level. Instances of centralized administration are the exception in the broader EU administrative framework. However, beyond the dichotomy of "direct vs. indirect administration," increasingly more forms of "shared administration" have emerged, where national and EU authorities cooperate with various intensities, in various ways, and at different moments of the decision-making process, in the implementation of EU law. In this context, a multi-level system of cooperation is being shaped that encompasses various levels: The regional/local, the national, and the EU levels. In this dense, multi-level administrative framework, administrative authorities at various levels of governance cooperate in putting EU law into effect. At the same time, and though not necessarily linked to the phenomenon of "shared administration," EU law has also contributed to the shaping of a system of "transnational administration," which refers to the possibility for an administrative act to have effect beyond its territory, with or without the need for recognition by the receiving Member State.

This Special Issue aims at examining the judicial and extra-judicial challenges arising from this complex and multi-layered system of cooperation. Its point of departure is, first, the observation that the administrative cooperation in the EU is multi- and cross-level, namely arising from the vertical cooperation between EU and national authorities or from the horizontal cooperation between national authorities themselves. Second, underlying the path of enquiry is the observation that, in the EU multilevel action, there might be decisions affecting natural and legal persons which cannot be judicially reviewed in an effective way. Third, in areas of extra-judicial cooperation, the lack of common standards or practices across Member States may undermine the effectiveness of EU policies and objectives.

The system of shared administration is present nowadays in virtually all EU policy fields, albeit with various shapes and intensities, such as competition law, the system of authorizations for the marketing of pharmaceutical products or genetically modified organisms (GMOs), data protection, the allocation of funds, and asylum policy. This Special Issue takes stock of this diversity, yet it does not aim to provide an all-encompassing overview of the system of shared administration in the European Union and its judicial and non-judicial challenges. Rather, it aims to go beyond the specific policy fields and tackle broad phenomena in the EU multi- and cross-level administrative framework.

In order to do so, this Special Issue discusses the rapidly emerging paradigm of transnational administrative acts (Dubos and Chevalier), the mechanism of mutual recognition in the European administrative space (Arroyo-Jiménez), the cooperation mechanisms in inspection activities (De Bellis) and in the field of maladministration (Athanasiadou and Vogiatzis), as well the implications of the system of shared administration for the control over the EU budget (Cipriani).

Furthermore, this Special Issue presents two emblematic cases in the field of GMOs authorizations (Eliantonio and Lanceiro) and asylum policy (Vavoula) in the vertical and horizontal system of administrative cooperation for the implementation of EU law. Both contributions, albeit sector-specific, are used to draw some overarching conclusions on the challenges in the EU multi- and cross-level administrative framework.

This introduction, after presenting the state of the art on the questions tackled by this Special Issue and highlighting its contribution to existing literature on the topic, presents a number of observations aimed to bring together various trends emerging from the Articles contained in this Special Issue. It also explores avenues for further research and reflection.

\footnotetext{
${ }^{1}$ See, e.g., Robert Schütze, From Rome to Lisbon: "Executive Federalism" in the (New) European Union, 47 COMMON MKT. L. REV. 1385 (2010).
} 


\section{B. The EU Multi- and Cross-Level Administrative Framework and its Challenges: The Extent of the Investigation so Far and the Open Questions}

The cooperative mechanisms in the European administrative space have been labelled differently ${ }^{2}$ and explored under various angles thus far. To date, commentators have examined various dimensions of the "integrated administration" in the $\mathrm{EU}^{3}$ and proposed typologies of "composite pro-

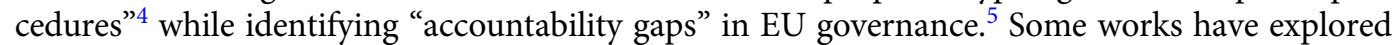
composite procedures in specific policy fields, ${ }^{6}$ or have discussed the role of European agencies in the system of integrated administration, ${ }^{7}$ or the implications of the CJEU's rulings where the legal questions linked to composite procedures have been tackled. ${ }^{8}$

\footnotetext{
${ }^{2}$ For example, the term Verwaltungskooperation (administrative cooperation) was used initially. See EBERHARD SCHMIDT-

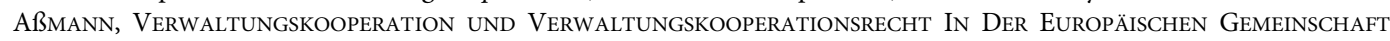
(1996). Other authors have spoken about amministrazione mista (mixed administration), see GIACINTO DELLA CANANEA \& Claudio Franchini, I Principi Dell'Amministrazione Europea (2010); and Verwaltungsverbund (administrative union), see Wolfgang Weiß, Der Europäische Verwaltungsverbund. Grundfragen, Kennzeichen, Herausforderungen (2010); “integrated administration," see Legal Challenges in EU Administrative LAW: Towards AN INTEgrated Administration (Herwig Hofmann \& Alexander Turk eds., 2009); “composite administration," see The European COMPOSITE ADMINISTRATION (Eberhard Schmidt-Aßmann \& Bettina Schöndorf-Haubold eds., 2011); or "co-administration," see JACQUES ZILLER, Les concepts d'administration directe, d'administration indirecte et de co-administration et les fondements du droit administratif européen, in Droit AdMINISTRATIF EUROPÉEN 235 (Jacqueline Dutheil de la Rochère ed., 2007).

${ }^{3}$ See generally Herwig Hofmann, Gerard C. Rowe \& Alexander H. Turk, Administrative Law and Policy of the European UnION 406 (2011); Herwig Hofmann, Decision-Making in EU Administrative Law-The Problem of Composite Procedures, 61 Admin. L. REv. 199 (2009). For a contribution focusing on the right to be heard see Christina Eckes \& Joana Mendes, The Right to be Heard in Composite Administrative Procedures: Lost in Between Protection?, 36 Eur. L.
} REV. 651 (2011).

${ }^{4}$ See generally Sergio Alonso de LeÓn, Composite Administrative Procedures in the European Union (2017); Filipe Brito Bastos, Derivative Illegality in the European Composite Administrative Procedures, 55 COMMON MKT. L. REV. 101 (2018); Giacinto Della Cananea, The European Union's Mixed Administrative Proceedings, 68 L. \& ConTEMP. ProBs. 197 (2005); Mariolina Eliantonio, Judicial Review in an Integrated Administration: The Case of "Composite Procedures," 7 REv. EuR. Admin. L. 65 (2014).

${ }^{5}$ Carol Harlow \& Richard Rawlings, Promoting Accountability in Multilevel Governance: A Network Approach, 13 EUR. L.J. 542 (2007); Mira Scholten, Shared Tasks, But Separated Controls: Building the System of Control for Shared Administration in an EU Multi-Jurisdictional Setting, 10 EUR. J. RISK REG. 538 (2019).

${ }^{6}$ Filipe Brito Bastos, Composite Procedures in the SSM and SRM-An Analytical Overview, in JUDICIAL REVIEW IN THE EURopean BANKING UNION 97 (Chiara Zilioli \& Karl-Philipp Wojcik eds., 2021); LAURA WissinK, EFFECTIVE LEGAL Protection in Banking Supervision: An Analysis of Legal Protection in Composite Administrative Procedures in the Single Supervisory Mechanism (2020); Mariolina Eliantonio \& Sabrina Röttger-Wirtz, From Integration to Exclusion: EU Composite Administration and Gaps in Judicial Accountability in the Authorisation of Pharmaceuticals, 10 EUR. J. RISK REg. 393 (2019); Laura Wissink, Ton Duijkersloot \& Rob Widdershoven, Shifts in Competences Between Member States and the EU in the New Supervisory System for Credit Institutions and Their Consequences for Judicial Protection, 10 Utrecht L. ReV. 92 (2014).

${ }^{7}$ See Controlling EU Agencies: The Rule of Law in a Multi-Jurisdictional Legal Order (Miroslava Scholten \& Alex Brenninkmeijer eds., 2020); LAw Enforcement By EU AuthoritiEs-Political and Judicial AcCountability in A SHAREd Legal Order (Michiel Luchtman \& Miroslava Scholten eds., 2017).

${ }^{8}$ See, e.g., Filipe Brito Bastos, The Borelli Doctrine Revisited: Three Issues of Coherence in a Landmark Ruling for EU Administrative Justice, 8 Rev. Eur. Admin. L. 269 (2015); Filipe Brito Bastos, Judicial Review of Composite Administrative Procedures in the Single Supervisory Mechanism: Berlusconi, 56 Common MKT. L. Rev. 1355 (2019); Simona Demková, The Grand Chamber's Take on Composite Procedures Under the Single Supervisory Mechanism: Comments on Judgment of 27 June 2018, 12 Rev. Eur. Admin. L. 209 (2019); Paul Dermine \& Mariolina Eliantonio, Case Note: CJEU (Grand Chamber), Judgment of 19 December 2018, 12 REV. EUR. AdMIN. L. 237 (2019); Menelaos Markakis, Composite Procedures and Judicial Review in the Single Resolution Mechanism: Iccrea Banca, 13 REv. Eur. AdmIN. L. 109 (2020); Paolo Mazzotti \& Mariolina Eliantonio, Transnational Judicial Review in Horizontal Composite Procedures: Berlioz, Donnellan, and the Constitutional Law of the Union, 5 EUR. PAPERS 41 (2020); Leo Neve, The Berlioz-Decision of the CJEU Provides Legal Protection for Concerned Persons in Transnational Setting, But Will it Hold in the International Area?, 10 Rev. Eur. Admin. L. 95 (2017); Catherine Warin, A Dialectic of Effective Judicial Protection and Mutual Trust in the European Administrative Space: Towards the Transnational Judicial Review of Manifest Error?, 13 REV. EUR. AdMin. L. 7 (2020). 
The global picture emerging is that of a regulatory paradigm that, while present since virtually the inception of the project of European integration, has not yet been fully and coherently explored and systematized. This Special Issue aims at further building on the earlier works on the system of administrative cooperation in the European Union from several perspectives.

First, this Special Issue addresses the extra-judicial, alongside the judicial, challenges in the EU multi- and cross-level administrative framework. While some studies have explored extra-judicial forms of control in the European multi-level administrative space, ${ }^{9}$ there is certainly scope to explore further the emerging challenges, both from the point of view of the individual as well as from the point of view of institutional collaboration. To that end, the institutions ${ }^{10}$ European Ombudsman and the European Court of Auditors along with their national peers- that have been selected, represent traditional avenues of extra-judicial accountability ${ }^{11}$ in the EU. Furthermore, one of the contributions, by Athanasiadou and Vogiatzis, seeks to identify similarities and, mostly, differences between the judicial and extra-judicial avenues of cooperation.

Second, two case studies are added to the fast-growing field of composite procedures: GMO authorizations and asylum. These case studies are representative in the field, as they exemplify procedures with a complex web of horizontal and vertical relationships between different national and EU actors, as well as the use of technological tools such as databases for the sharing of information. ${ }^{12}$ In this context, this Special Issue aims to uncover, through these two case studies, possible general patterns in judicial challenges for the multi- and cross-level system of EU administrative cooperation.

Third, this Special Issue adds to the existing knowledge on composite procedures more generally, which so far has predominantly focused on multi- and cross-level decision-making procedures. This Special Issue adds the enforcement aspect to the analysis by examining the topic of shared inspection procedures, which has thus far not been subject to systematic investigation. This is an important contribution to our understanding of the challenges arising from administrative cooperation in the EU, because of the particular fundamental rights implications of those activities when they take place in a multi-level context.

Fourth, this Special Issue brings to the fore and explores the link between the notions of shared and transnational administration. While with the first term, reference is made to decision-making processes involving multiple jurisdictions participating at different moments and with different intensities, ${ }^{13}$ the second term refers to the capacity of an administrative act to have effects outside the territory where the issuing authority is situated. While the two terms may overlap, in that composite procedures may culminate in the adoption of a transnational administrative act, this is not always and not necessarily the case. Furthermore, while the notion of transnational administrative acts has been developed in the context of the debate surrounding the system of mutual

\footnotetext{
${ }^{9}$ See generally Harmut Aden, The European Court of Auditors and its Relationship with National Independent Audit Institutions: The Evolving Audit Function in the EU Multilevel System, in The Palgrave Handbook OF THE EURopean Administrative System 313 (Michael Bauer \& Jarle Trondal eds., 2015); Nikos Vogiatzis, Revisiting the Mandate and Practice of the European Ombudsman, in The European OMbUdSMAN ANd Good Administration IN THE EUROPEAN Union 185 (2018); Nikos Vogiatzis, The Independence of the European Court of Auditors, 56 CommON MKT. L. REV. 667 (2019).

${ }^{10}$ The term "institutions" is used in a broader sense and does not refer to Article 13 TEU. After all, the European Ombudsman is not included therein.

${ }^{11}$ For a full picture it must be accepted, though, that certain domestic Supreme Audit Institutions are of judicial charactercontrary to the European Court of Auditors.

${ }^{12} \mathrm{On}$ the topic of information sharing in the context of composite procedures, see Deirdre Curtin \& Filipe Brito Bastos, Interoperable Information Sharing and the Five Novel Frontiers of EU Governance: A Special Issue, 26 EUR. PUB. L. 59 (2020); Diana-Urania Galetta, Herwig C.H. Hofmann \& Jens-Peter Schneider, Information Exchange in the European Administrative Union, 20 Eur. Pub. L. 65 (2014). See also Mariolina Eliantonio, Information Exchange in European Administrative Law: A Threat to Effective Judicial Protection?, 23 MaAsTricht J. Eur. \& CoMP. L. 531 (2016).

${ }^{13}$ For this definition, see Mariolina Eliantonio, Judicial Review in an Integrated Administration: The Case of "Composite Procedures", 7 REv. Eur. AdMIN. L. 65 (2014).
} 
recognition, ${ }^{14}$ this type of act may well arise beyond a paradigm of mutual recognition. Despite the capital importance in the system of European administrative integration, the notion of transnational administration has not been the subject of much analysis, especially in English, and studies have remained mostly theoretical. ${ }^{15}$ This Special Issue aims to advance the conceptual understanding of the notion of transnational administration in the European Union; it seeks to disentangle the relationships between composite procedures and transnational administrative acts, on the one hand, and transnationality and mutual recognition, on the other hand, and discuss the challenges these mechanisms pose in terms of judicial protection.

\section{This Special Issue in Further Detail: Key Issues and Common Themes}

This Special Issue starts with the Article by Chevalier and Dubos on transnational administrative acts. These are acts that concern at least two national legal orders by reason of "the authority that adopted them, the scope of their effects, their addressee(s), and/or their decision-making process." ${ }^{16}$ A taxonomy of these acts is offered, on the basis of whether the act is with or without "transnational imputation" and with or without "transnational effects." ${ }^{\prime 7}$ Further, when examining the principles that determine the competent court, the key aim is to uncover challenges in the availability of judicial review in the aforementioned cases. Relying on the well-known principle of effective judicial protection, the authors claim that "the softness of the borders of administrative action requires the softening of those surrounding the system of judicial review." 18

Arroyo Jiménez, in his contribution, focuses on a particular type of transnational administrative arrangement, namely the mechanism of mutual recognition-that is, "a regulatory arrangement under which the administrative or judicial authorities of one Member State must give legal effects within their territory to rules or acts passed by the legislative, administrative or judicial authorities of another Member State"19 — in the European administrative space. Again, the aim is to explore gaps in judicial protection or "judicial control blind spots arising in horizontal interactions." ${ }^{20}$ After an exposition of key principles surrounding the development, content, and context of effective judicial protection within the EU legal order, the different forms of mutual recognition are explored. The Article unravels the problems that may arise in judicial review regarding procedure, the law that must be applied, deference, and standards or review.

\footnotetext{
${ }^{14}$ See Giacinto della Cananea, From the Recognition of Foreign Acts to Trans-National Administrative Procedures, in Recognition of Foreign Administrative Acts 219 (J. Rodriguez-Arana Muñoz ed., 2016); Herwig C.H. Hofmann, Gerard C. Rowe \& Alexander Turk, Administrative Law and Policy of the European Union 645 (2011) (discussing the "transterritorial application of national decisions"); Juan José Pernas García, The EU's Role in the Progress Towards the Recognition and Execution of Foreign Administrative Acts: The Principle of Mutual Recognition and the Transnational Nature of Certain Administrative Acts, in ReCOGNITION OF ForEIGN AdMINISTRATIVE ACTs 15 (J. Rodriguez-Arana Muñoz ed., 2016); Stefano Dorigo, Mariolina Eliantonio \& Rui Lanceiro, The Principle of Mutual Recognition in European Administrative Law, 13 Rev. Eur. Admin. L. 183 (2020); Angelos S. Gerontas, Deterritorialization in Administrative Law: Exploring Transnational Administrative Decisions, 19 Colum. J. Eur. L. 423 (2013); Luca De Lucia, Administrative Pluralism, Horizontal Cooperation and Transnational Administrative Acts, 5 Rev. Eur. AdmIN. L. 17 (2012); Luca De Lucia, From Mutual Recognition to EU Authorization: A Decline of Transnational Administrative Acts?, 1 ItALIAN J. PUB. L. 90 (2016); Henrik Wenander, Recognition of Foreign Administrative Decisions, 71 ZAÖRV 755 (2011).

${ }^{15}$ See, e.g., Marie Gautier, Acte administratif transnational et droit de l'Union européenne, in DroIT ADMINISTRATIF Européen, supra note 2, at 1303; Luca De Lucia, Amministrazione Transnazionale E Ordinamento Europeo (2009); Florian Schwetz, GrenzÜberschreitende Verwaltungsakte Transnationalität, Gegenseitige ANERKENNUNG UND VerWALtungSENTSCHEIdUngen IM MEHREBENENSYSTEM (2021); Joachim Becker, Der transnationale Verwaltungsakt: übergreifendes europäisches Rechtsinstitut oder Anstoss zur Entwicklung mitgliedstaatlicher Verwaltungskooperationsgesetze?, 116 DeUtsChes VerwaltungSBLATT 855 (2001).

${ }^{16}$ Chevalier \& Dubos, The Notion of "Transnationality" in Administrative Law: Taxonomy and Judicial Review, in this issue. ${ }^{17} I d$.

${ }^{18} I d$.

${ }^{19}$ Arroyo Jiménez, Effective Judicial Protection and Mutual Recognition in the European Administrative Space, in this issue. ${ }^{20} I d$.
} 
Lanceiro and Eliantonio then shift attention to include vertical cooperation as well. Their case study is the Genetically Modified Organisms (GMOs) regime, which is characterized as a "playground" for multi-level administration, yet a "nightmare" for effective judicial protection. The level of complexity is apparent after careful consideration of the two main legal instruments surrounding genetically modified food and feed under Regulation 1829/2003 and GMOs for uses other than food and feed, notably for cultivation or industrial uses under Directive 2001/18. They observe that common features in both procedures are a risk assessment by the European Food Safety Authority and "the presence of various moments to pre-empt political or judicial confrontation, and provide incentives for consensus." 21 This, however, results in gaps in judicial protection, which the existing caselaw of the Court of Justice can only partially address.

Information sharing in the context of asylum policy is the focus of the next Article in the Special Issue, by Vavoula. Here, the focus is predominantly on horizontal cooperation, although the role of the European Data Protection Supervisor is briefly recalled. Vavoula argues that the applicable rules concerning Eurodac, "an EU-wide centralized information system which is aimed at assisting in the determination of the responsible Member State through the joint gathering of information," 22 does not provide for sufficient and effective remedies for asylum seekers. Challenges for national courts include the difficulties in reviewing irregular registrations in Eurodac and transfers in breach of Article 34 of the Dublin III Regulation. In terms of extrajudicial remedies, recourse to national Data Protection Authorities (DPAs) is rarely used by individuals.

The next contribution adds the enforcement aspect to the picture: Shared inspection procedures is the focus of De Bellis' Article. Beyond effective judicial protection, De Bellis focuses on the inviolability of the home, which is protected by both the European Convention of Human Rights (ECHR) and the EU Charter. The Article draws primarily on the principles developed by the Strasbourg Court in its jurisprudence in order for inspections to be lawful, but, also, at places on the domestic experience of certain Member States. Applying these considerations in the EU legal order and reviewing the case-law of the Luxembourg Court, which has accepted that "the lack of ex ante judicial authorization can be counterbalanced through procedural guarantees and ex post judicial control," ${ }^{23}$ De Bellis concludes that the current remedies "fall short in providing a full ex post judicial scrutiny, in particular when these powers are used in the context of composite procedures." 24

This Special Issue then considers more closely extra-judicial challenges, starting with ombud institutions and the cooperation between the European Ombudsman and her peers. The focus of Athanasiadou's and Vogiatzis' Article is on the "EU queries," ${ }^{25}$ a scheme that enables a national office to submit a query on EU law to the European Ombudsman and receive a reply. The origins and development of such cooperation, as well as an analysis of all of the queries published to date on the European Ombudsman's website, "with a view to systemizing their subject matter and assessing the legal characteristics of the given responses," 26 is provided. A comparison with the preliminary reference procedure underlines the differences, but also complementary function, and ultimately added value, thanks to its speed and flexibility, of the EU queries process in

\footnotetext{
${ }^{21}$ Lanceiro \& Eliantonio, The Genetically Modified Organisms' Regime: A Playground For Multi-Level Administration And A Nightmare For Effective Judicial Protection?, in this issue.

${ }^{22}$ Vavoula, Information Sharing in the Dublin System: Remedies for Asylum Seekers In-Between Gaps in Judicial Protection and Interstate Trust, in this issue.

${ }^{23}$ De Bellis, Multi-level Administration, Inspections and Fundamental Rights: Is Judicial Protection Full and Effective?, in this issue.

${ }^{24} I d$.

${ }^{25}$ Athanasiadou \& Vogiatzis, The EU Queries: A Form of Extra-Judicial Preliminary Reference in the Field of Maladministration?, in this issue.

${ }^{26} I d$.
} 
the effective and coherent application of EU law. Nonetheless, several challenges are also identified.

This Special Issue concludes with a contribution from Cipriani on the budgetary arrangements in the EU's multilevel setting, with a particular focus on the role of the European Court of Auditors (ECA), which-despite its name-is another extra-judicial institution. As Cipriani explains, although the Commission formally assumes responsibility for the implementation of the budget, in practice this is implemented primarily by various domestic authorities. In this context, the role of the ECA in improving accountability is particularly challenging. It is claimed that a stronger focus on performance or "value for money" audit is required, and also that "the approach based on 'error rates' risks to promote wrong incentives and ineffective protection of taxpayers' money." 27 In addition, national audit offices could play a key role regarding the follow-up to recommendations addressed to Member States.

From the above brief presentation of the seven contributions to this Special Issue, it is possible to identify a number of common themes or concerns that emerge from some or most of the Articles. To begin with, clearly the principle of effective judicial protection arguably permeates the first five Articles of this Special Issue. Effective judicial protection features in Article 47 of the Charter and stems also from Articles 6 and 13 ECHR, but its development in the EU legal order well predates the Charter. ${ }^{28}$ It is the imperative of effective judicial protection that prompts inquiries about the need to "soften the borders" in terms of review of transnational acts; to pay close attention to different forms of mutual recognition and the challenges of judicial review arising thereof; to consider the gaps in the review of procedures regarding GMOs, information sharing within the asylum system in the EU, or multi-level inspection activities.

Within the multi- and cross-level European administrative governance, there is indeed an inherent tension between the requirement of effective judicial protection, on the one hand, and the system of separation of jurisdiction and the principle of territoriality, on the other hand. The system of separation of jurisdiction-inspired by a strict adherence to the traditional doctrine of executive federalism - requires that the judicial authority competent for reviewing an administrative act be, in cooperative procedures between EU and Member State authorities, that of the system to which the act of the procedure belongs. The principle of territoriality, relevant in cooperative procedures between national authorities, is inspired by considerations of sovereignty and prevents a judicial instance from reviewing acts attributable to authorities of another sovereignly equal Member State. The Articles of this Special Issue show that, while procedural decisionmaking integration is a reality in virtually all EU policy fields, the default judicial disintegration might often be at odds with the requirement of effective judicial protection.

If this Special Issue is able to expand the discussion on the challenges arising on the basis of vertical cooperation via zooming in on selected areas, it also invites us to think carefully about horizontal cooperation as well, an area which has been less studied in the literature, and where the caselaw is possibly less mature than that with respect to vertical cooperation. Horizontal cooperation and the transnational nature of the acts and decisions that it generates is at the core of the contributions by Chevalier and Dubos; Arroyo Jiménez; and Vavoula. The limitations in the review of the "court of destination," to refer to the terminology by Arroyo Jiménez, are apparent throughout these Articles. One example - among many others — offered by Arroyo Jiménez is the uncertainty about the interpretation of the law of origin that the court of destination might face. The possibility of several courts

\footnotetext{
${ }^{27}$ Cipriani, Improving the accountability of the EU budget's multi-level implementation: Strengthening the contribution of the European Court of Auditors, in this issue.

${ }^{28} \mathrm{See}$ Arroyo Jiménez, in this issue. For an overview of the complex genesis of the principle of effective judicial protection and its relationship with the principle of effectiveness and the right to an effective remedy, see Sacha Prechal \& Rob Widdershoven, Redefining the Relationship Between 'Rewe-Effectiveness' and Effective Judicial Protection, 4 REv. EuR. Admin. L. 31 (2011). See also Mariolina Eliantonio \& Elise Muir, The Principle of Effectiveness: Under Strain?, 12 REV. EUR. AdMIN. L. 255 (2019).
} 
considering that they have jurisdiction to review an administrative act also entails a risk of contradictions in the assessment of the legality of an administrative act, as Chevalier and Dubos remind us.

Yet the discussion on extra-judicial challenges also brings to the fore the challenges arising from vertical cooperation. If instances of maladministration occur at the domestic level, and if the European Ombudsman's remit does not extend therein, does this not impose a duty on the European and national ombud offices to find suitable forms of cooperation while respecting their respective remits? And if the ECA's audit mandate is rather broad, does this not impose a duty on the ECA and the national audit offices to find appropriate ways of collaboration within the spirit of Article 287(3) TFEU ${ }^{29}$ The aforementioned Articles on maladministration and audit seek to reflect on these challenges as well.

If one could use a metaphor, a "cloud" surrounding some of these challenges is the question of trust. This path of enquiry certainly applies to the transnationality of administrative acts and the system of mutual recognition, but in this Special Issue it is exemplified in the contribution by Vavoula. Therein, Vavoula questions, among other things, the "presumption of trust" in the administrative practices of other Member States or indeed the tension between trust and effective judicial protection: "[T]he tension between trust in modern technologies and administrative procedures-fingerprint registration in Eurodac-taken place in other Member States, which may not be infallible, and the need to safeguard the fundamental rights of asylum seekersparticularly their right to an effective remedy." ${ }^{30}$ Elsewhere, further trust is perhaps being called for: Cipriani's contribution underlines the limitations of the ECA's resources and argues that follow-up to recommendations addressed to Member States could be undertaken by national audit offices. But Cipriani also claims that "broadening the geographical scope of the audit work would enhance the possibility of drawing conclusions beyond the current limited number of member states visited." 31 The above observations entail that formidable legal doctrines can be established on trust, and excellent formulations may feature in the treaty or elsewhere, as is the case, for example, with Article 287(3) TFEU, but trust across Member States or between national and EU authorities is neither a given nor an impossibility: It requires careful consideration of the particular arrangements across policy fields, examination of domestic and EU jurisprudence, reports and other documents published by extra-judicial institutions, and, of course, consideration of empirical evidence.

Lastly, all of the Articles in this Special Issue, either briefly or more extensively, think about possible solutions to the problems that they have identified. A comprehensive picture can be found in the subsequent Articles, yet certain illustrative examples may be mentioned here. Chevalier and Dubos reflect on the ways and the extent of which a national court can review a foreign act on grounds of EU law. Arroyo Jiménez explores, in the mechanism of mutual recognition, opportunities emerging from the doctrines of Eurobolt ${ }^{32}$ and Berlioz. ${ }^{33}$ The potential of the latter judgment is also recognized by Lanceiro and Eliantonio, with a view to addressing certain of the gaps in judicial protection, as it enables a national court to review the lawfulness of

\footnotetext{
${ }^{29}$ This article provides, inter alia, that "[ $\left.\mathrm{t}\right]$ he Court of Auditors and the national audit bodies of the Member States shall cooperate in a spirit of trust while maintaining their independence." Consolidated Version of the Treaty on the Functioning of the European Union art. 287(3), Oct. 26, 2012, 2012 O.J. (C 326) 47.

${ }^{30}$ Vavoula, Information Sharing in the Dublin System: Remedies for Asylum Seekers In-Between Gaps in Judicial Protection and Interstate Trust, in this issue.

${ }^{31}$ Cipriani, Improving the accountability of the EU budget's multi-level implementation: Strengthening the contribution of the European Court of Auditors, in this issue.

${ }^{32}$ ECJ, Case C-644/17, Proceedings Brought by Eurobolt BV, ECLI:EU:C:2019:555 (July 3, 2019), http://curia.europa.eu/ juris/liste.jsf?num $=\mathrm{C}-644 / 17$.

${ }^{33}$ ECJ, Case C-682/15, Berlioz Inv. Fund SA v. Directeur de l'administration des contributions directes, ECLI:EU: C:2017:373 (May 16, 2017), http://curia.europa.eu/juris/liste.jsf?num=C-682/15.
} 
acts taken by foreign authorities in order to comply with Article 47 of the Charter. Vavoula claims that a "more thorough" investigation is required by both domestic courts and national administrations, which could circumvent the presumption of trust and the limitations of judicial review. De Bellis calls for an action for annulment of the decision to inspect in areas where this is not possible and EU authorities do have inspection powers, while also inviting, in essence, the Luxembourg Court to pay closer attention to the jurisprudence of the Strasbourg Court. Athanasiadou and Vogiatzis argue that, in order to improve the transparency and effectiveness of the "EU queries" scheme, a "more formalized approach is needed," in that the EU queries would "benefit from clearly delineating its features, outcome and added value vis-à-vis other instruments." 34 Lastly, Cipriani advances a clearer focus on performance audit regarding the ECA's work, further scrutiny across the ECA's audit chambers' thematic responsibilities, and more intensive cooperation with national offices regarding Member State compliance with its recommendations.

\section{Avenues for Further Research and Reflection}

The Articles in this Special Issue have sought to grapple with the challenges arising in the EU multi- and cross-level administrative framework. While administrative vertical and horizontal cooperation is an ever more prevalent feature of the European administrative space, the phenomenon still deserves further attention and scholarly analysis.

First, the relationship between separation of jurisdictions and the principle of territoriality, on the one hand, and the requirement of effective judicial protection, on the other hand, is far from settled. With incremental moves and somewhat ad hoc solutions, the Court of Justice has tried to move to a more "holistic" system of judicial review; however, the emerging picture is still in flux. In this respect, questions that would merit further exploration include the following: Will Berlioz find application beyond the field of mutual assistance in tax matters? Does Berlusconi not limit the review of the Court of Justice solely to illegalities arising from EU law, while leaving illegality stemming from the violation of national law in effect immune from judicial review? How can one imagine a "holistic" judicial review when composite procedures are at the same time both horizontal and vertical? How could and should the Court of Justice's caselaw be of applications in procedures in which the input of the concerned actors is not formalized and can thus be hard to disentangle in the decision-making process? In this respect, it should be remembered that "jurisdictional boundaries" are still the default position, and the dilemmas that the Court is facing should be acknowledged. ${ }^{35}$ One could even speak of challenges that the Court itself is facing when addressing judicial gaps that arise in the inevitable forms of vertical and horizontal cooperation in the EU.

Second, and linked to the first point, there is potential to explore where extra-judicial avenues of control might serve as alternatives to tackle the shortcomings of the judicial control mechanisms. To some extent, the exposition of the "EU queries" system in comparison with the preliminary reference already indicates the possible complementarity, if not the added value, of the extra-judicial avenue. Readers might be aware, of course, of some of the general advantages of extra-judicial avenues, which may include more relaxed or no locus standi requirements, reduced or no costs, flexibility, speed, a non-adversarial nature, and others. A widely used phrase of the second European Ombudsman was that there is "life beyond legality." 36 And, indeed, one assumes that there may be some kind of trade-off between flexibility, understood in a broad sense

\footnotetext{
${ }^{34}$ Athanasiadou \& Vogiatzis, The EU Queries: A Form of Extra-Judicial Preliminary Reference in the Field of Maladministration?, in this issue.

${ }^{35}$ See Filipe Brito Bastos, Luxembourg $v$ B: How Far Should Jurisdictional Limits Be Eroded in the Name of Effective Judicial Protection?, 41 EU L. LIVE 10 (2020).

${ }^{36}$ See also Vogiatzis, Revisiting the Mandate and Practice of the European Ombudsman, supra note 9, at 13.
} 
to include the aforementioned elements, and legally binding decisions; one often cannot have both, and a careful consideration of the appropriate avenue would be required. Nevertheless, this Special Issue invites further reflection and investigation of such synergies, particularly in the field of composite procedures. De Bellis" contribution identifies "judicial gaps" in inspections: With the aforementioned limitations under which an extra-judicial office, such as the European Ombudsman, operates, is there scope for the latter to provide some relief? One would note, in this respect, that the European Ombudsman's mandate extends to "activities," not "acts," and that the office has already produced "ombuds-prudence" regarding OLAF, for example, that would certainly require further investigation.

In addition, the contribution by De Bellis, in particular, raises the interesting question as to whether further research might be needed so as to unravel points of convergence or divergence in terms of human rights jurisprudence of the two European courts. Of course, the evolving relationship between the Strasbourg and Luxembourg Courts has been thoroughly examined in the literature. Nevertheless, one wonders if in the field of composite procedures, in particular, there may be further opportunities for comparative investigation, including, but also going beyond, privacy and data protection.

Last, and beyond the question of judicial and non-judicial control of composite procedures, the patterns of cooperation in the EU multi- and cross-level administrative framework are certainly worthy of further exploration. Vavoula argues, for example, that "recourse to vertical cooperation seems a sensible solution" in light of the "forthcoming interoperability of EU information systems." ${ }^{37}$ Earlier research has shown that horizontal cooperation, often based on values of mutual trust and expressed in various patterns of mutual recognition, is being progressively eroded by centralizing tendencies in the EU regulatory framework. ${ }^{38}$ Similarly, it has been shown that enforcement-traditionally the monopoly of national authorities - is increasingly placed within multi-level ${ }^{39}$ or purely European regulatory structures. ${ }^{40}$ In this context, this Special Issue shows that there is certainly scope for a coherent study across policy or policies with a view to identifying how the various cooperative patterns - horizontal and vertical-have evolved, the reasons behind each institutional design, and the issues that remain unresolved.

\footnotetext{
${ }^{37}$ Vavoula, Information Sharing in the Dublin System: Remedies for Asylum Seekers In-Between Gaps in Judicial Protection and Interstate Trust, in this issue.

${ }^{38}$ See, e.g., W.H. Roth, Mutual Recognition, in ReSEARCh HANDbook on the LAW of the EU's Internal Market 429 (Panos Kourakos \& Jukka Snell eds., 2017) (concerning the field of financial regulation); Luca De Lucia, From Mutual Recognition to EU Authorization: A Decline of Transnational Administrative Acts?, 1 ITALIAN J. PuB. L. 90 (2016) (providing examples of the setting up of the European Railway Agency and the regulation of novel food).

${ }^{39}$ See, e.g., Federica Cacciatore \& Mariolina Eliantonio, Quis custodiet ipsos custodes? Assessing the Systems of Controls of the European Fisheries Control Agencies Inspecting Powers, in ConTrolling EU Agencies: The Rule OF LAW IN A MultiJURISDictional LEgAL ORder 215 (Miroslava Scholten \& Alex Brenninkmeijer eds., 2020).

${ }^{40}$ See, e.g., Miroslava Scholten, Mind the Trend! Enforcement of EU Law Has Been Moving to "Brussels", 24 J. EuR. PUB. POL'Y 1348 (2017).
}

Cite this article: Eliantonio M, Vogiatzis N (2021). Judicial and Extra-Judicial Challenges in the EU Multi- and Cross-Level Administrative Framework. German Law Journal 22, 315-324. https://doi.org/10.1017/glj.2021.18 